Ethiopian Journal of Environmental Studies \& Management 9 (1): 22 - 34, 2016.

ISSN:1998-0507

Submitted: July 06, 2015

doi: http://dx.doi.org/10.4314/ejesm.v9i1.3

Accepted: January 07, 2015

\title{
DISTRIBUTION, DIVERSITY AND ABUNDANCE OF ANURAN SPECIES IN THREE DIFFERENT VEGETATION HABITATS IN SOUTHWESTERN NIGERIA
}

ONADEKO, A.B.

Department of Zoology, Faculty of Science, University of Lagos, Akoka, Lagos, Nigeria Email: aonaddeko@unilag.edu.ng

\begin{abstract}
The distribution, diversity and abundance of anuran species in three different vegetation habitats of Southwestern Nigeria were investigated. A total mean number of 388 individuals comprising 32 species were observed in the forest, 766 individuals in 28 species were recorded in the fallowed farmland and 278 individuals in 21 species in the savanna. There was significant difference $\left(F_{2,129}=3.602\right)$ between the numbers of anuran species inhabiting the three vegetation habitats at $P<0.05$ as well as significant difference $\left(F_{2,129}=5.811\right)$ between the number of individuals of anuran species in the three vegetation habitats $(P<0.01)$. The dominant species in the forest was Arthroleptis variabilis (9.02\%) and the least abundant species in the forest were Leptopelis macrotis, Phlyctimantis boulengeri and Nectophryne afra each having $0.26 \%$. Amietophrynus maculatus and A. regularis were both abundant in the fallowed farmland and savanna habitats. The least abundant species in the fallowed farmland was Leptopelis calcaratus $(0.13 \%)$ while the least abundant in the savanna were Xenopus muelleri and Afrixalus dorsalis each with $0.72 \%$. Thirty percent of anuran species observed occurred in all the vegetation habitats, while $27 \%, 11 \%$ and $7 \%$ were restricted to the forest, fallowed farmland and savanna respectively. Most amphibian species were observed and collected between the 18h-21h sampling time frame which confers them as mostly nocturnal in habit. Conservation efforts must be enforced to protect the vegetative structure against unsustainable forest practices in order to protect and maintain the biodiversity status of the region.
\end{abstract}

Key Words: Distribution, Diversity, Nigeria, Vegetation, Forest and Savanna

\section{Introduction}

The first major threat to populations of amphibians is habitat destruction. Throughout the history of civilization, human activities have been detrimental to the natural biota (Duellman and Trueb, 1986). This is particularly evident in the clearing of the forest which houses the greatest diversity of anurans.
Forest destruction caused by anthropogenic activities such as bush burning, farming, grazing and urbanization have over several millennia changed the original vegetation cover across the world especially the forest regions (Schiotz, 1963; Adejuwon, 1976; Ogigirigi, 1986; Bakarr et al., 2001 and Boone and Bridges, 2003). 
This has had a negative impact on the ability of amphibians to thrive and reproduce successfully (Blaustein and Bancroft, 2007 and Becker et al, 2007). These phenomena have caused the disappearance of biodiversity.

Forest harvesting in Africa has evolved considerably since 1950 (FAO, 1985b). In Nigeria, the net volume of logs utilized is still fairly limited where domestic markets have supplanted exports as compared to other countries such as Congo and Gabon where 75 percent of the timber trade volume consists of exports (Kio et al., 1985). Presently in Nigeria, about $65.2 \%$ of the vegetation has been lost to agricultural practices and only $4.9 \%$ are undisturbed, mangrove and montane forests (www.fao.org). NEST (1991), described the plant cover of the country as a patchwork of farmlands, plantations and secondary vegetation at varying stages of regrowth and maturity. Perhaps the most matured regrowth vegetation exists in areas that have been set aside as forest or game reserves, in fetish groves outside the reserves or in remote inaccessible areas (NEST, 1991).

Ayobami (1988) observed that vegetation modification and man-induced environmental change in rural Southwestern Nigeria has negatively affected the soil-vegetation system especially caused by the shifting agricultural cultivation of peasant farmers As a result of these agricultural practices especially shifting agriculture, a lot of vegetation which were originally forest is left to fallow eg. fallowed farmlands which are of various degrees of growth. These fallowed farmlands form a major part of the vegetative structures, therefore also constituting a habitat for amphibian species. Also according to Udo (1970), apart from the forest forming one of the major vegetation, the savanna (insignificant tree cover, with grasses and flowers located between the trees) which is drier forms a major vegetation cover in Nigeria. This paper documents the diversity, distribution and abundance of amphibian species in these three vegetation regions of Southwestern Nigeria which are the forests, fallowed farmlands and savanna.

\section{Materials and Methods \\ Study Area}

The states in which the study was conducted were Oyo, Ogun and Lagos States in Southwestern Nigeria. Lagos State is situated between Latitude $6.4^{\circ}$ and $6.67^{\circ} \mathrm{N}$ and longitude $2.7^{\circ}$ and $4.43^{\circ} \mathrm{E}$; Ogun State between Latitude $6.3^{\circ}$ and $7.75^{\circ} \mathrm{N}$ and Longitude $2.7^{\circ}$ and $4.6^{\circ} \mathrm{E}$; and Oyo State between Latitude $7.08^{\circ}$ and $9.2^{\circ} \mathrm{N}$ and Longitude $2.7^{\circ}$ and $4.55^{\circ} \mathrm{E}$ (Figure 1). 


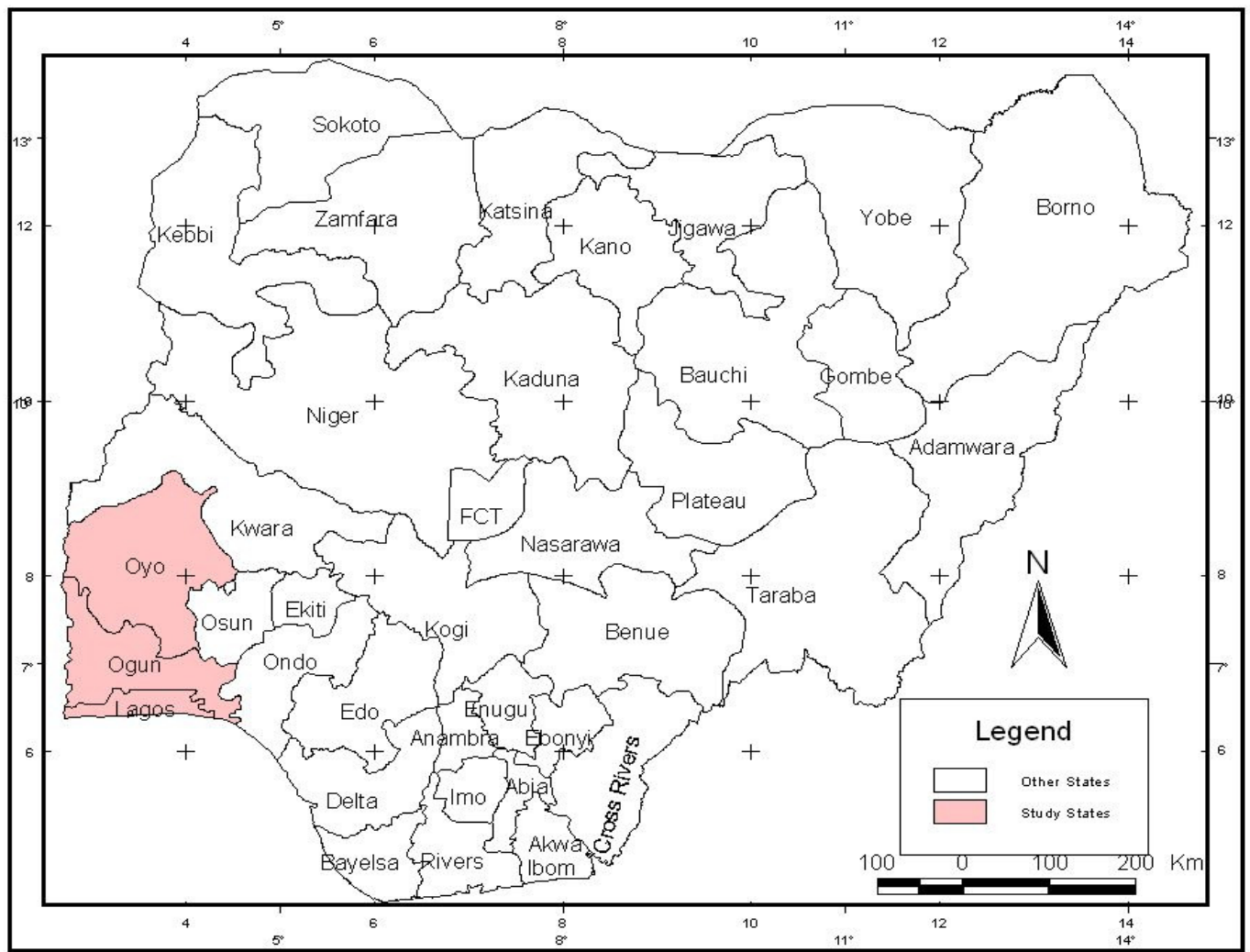

Figure 1: States of Lagos, Ogun and Oyo in Nigeria where study sites were located.

\section{Sampling Design and Methods}

Selection and Sampling of Study Sites

Several of the study sites selected was visited previously between July 2003 and December 2004 (Onadeko and Rodel, 2009) for amphibian surveys. Each of these sites had an approximate size of about $30,000 \mathrm{~m}^{2}$ and their position taken with the Global Positioning System (G.P.S.). These chosen sites were representative of the vegetative zones (forest, fallowed farmland and savanna zones) within the study area.

Sampling was carried out early morning (6-9h), afternoon (12-15h) and at night (18-21h) by a team of four individuals. Each site was visited twice a year with two days of intensive work to cover the sampling time frame during the rainy season from 2005-2007. The climatic data (rainfall and temperature) were recorded from four stations location at Ikeja, Ijebu Ode, Ibadan and Ilorin. Ikeja is in Lagos State which is the southernmost position (freshwater and moist forest zone); Ijebu Ode and Ibadan are located in Ogun State occupying the middle region (moist and deciduous forest); and Ilorin is in the northern most region (savanna) at the border of Oyo State. The extracted data of these climatic stations were corroborated with the vegetation types.

Amphibian specimens were located opportunistically by careful examination of suspected refuges and hiding places such as under stones, fallen wood, panels, plastics and amongst leaf litter. Vegetation surrounding and overhanging aquatic environments were searched thoroughly. There was careful inspection of broad leaved hydrophytes that harboured arboreal species. Hand dipnets (model WTG-E006) 
with mesh size of $10 \mathrm{~mm}$ were used to sample temporary and permanent water bodies for aquatic species such as Silurana and Xenopus. Subterranean species such as Hemisus were located mainly by their vocalization after leaving their burrows during heavy rains. The visual encounter survey (VES) and acoustical encounter survey (AES) were sampling techniques applied mainly during the day time and night time surveys respectively (Rodel and Ernst, 2004).

\section{Site Classification}

Based on the vegetation type, each study site was classified either as forest (consisting of primary and secondary forests); fallowed farmland (degraded forest and altered land in the former forest zone consisting of different stages of vegetation growth up to tertiary level); and savanna (consisting of savanna and derived savanna) (Table 1).

The forest was classified either as primary or secondary based on the density of vegetation (open, gaps predominating, closed areas predominating or closed) and plant diameter at breast height(dbh) (dbh: 0-5, 6-10, 11-20, 21-50 and above 50cm) (Conant and Joseph, 1998).

Table 1: Classification of study sites into vegetation region/habitat

\begin{tabular}{llll}
\hline Habitat Classification & & & \\
\hline Vegetation Regions & Forest & Fallowed farmland & Savanna \\
Collection Sites & LA 04, LA 07, & LA 01, LA 02, & OG 04, OG 05, \\
& LA 09, OG 02, & LA 03, LA 05, & OY 01, OY 04, \\
& OG 03, OG 06, & LA 06, LA 08, & OY 05, OY 06, \\
& OG 08, OG 10, & LA 10, LA 11, & OY 07, OY 08, \\
& OG 12, OY 02, & OG 01, OG 07, & OY 09, OY 10, \\
& OY 03 & OG 09, OG 11 & OY 11 \\
\hline
\end{tabular}

$\mathrm{LA}=$ site in Lagos State; $\mathrm{OG}=$ site in Ogun State; and OY = site in Oyo State

Forest $=$ (secondary and primary forests)

Fallowed farmland $=($ degraded forest and altered land in former forest zone consisting of different stages of vegetation growth up to tertiary level)

Savanna $=($ savanna and derived savanna $)$

\section{Statistical Analysis}

The diversity indices of anuran taxa inhabiting the three vegetation zones were analyzed (using SPSS Ver. 16) and the distribution of the anuran species and their abundance were tested for significant difference using the Analysis of Variance (ANOVA). Multiple comparisons of significantly different means were also analyzed. The faunal similarities of the three zones were tested using Sorenson's quotient $(\mathrm{Q} / \mathrm{S})$.

\section{Results \\ Climatic Data}

The climatic data of Southwestern Nigeria was summarized from four meterological stations located at Ikeja, Ijebu Ode, Ibadan and Ilorin (Figure 2). These stations gave a general view of the climatic conditions covering the forest to savanna zones. The highest and lowest mean rainfall of $133.11 \mathrm{~mm}$ and $67.93 \mathrm{~mm}$ were recorded at Ikeja and Ilorin respectively, while the highest and lowest mean temperatures of $33{ }^{\circ} \mathrm{C}$ and $31{ }^{\circ} \mathrm{C}$ were recorded at Ilorin and Ikeja respectively. 


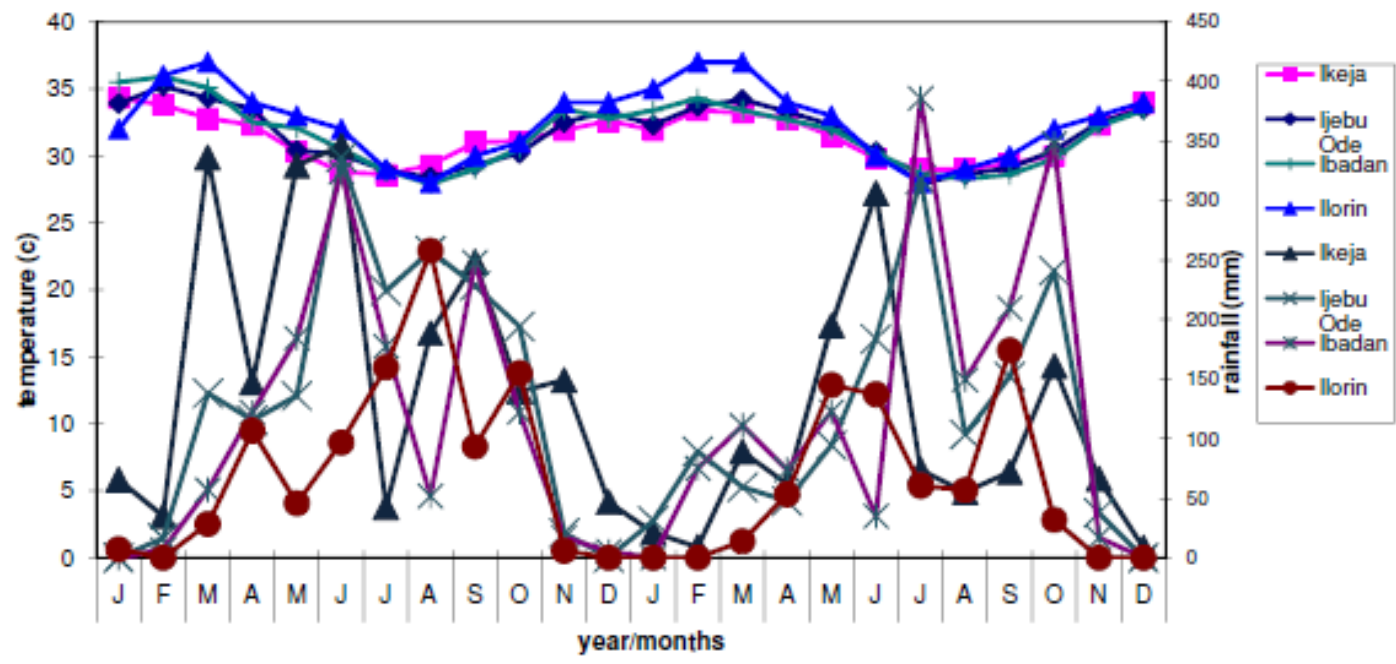

Figure 2: Monthly rainfall and averaged monthly temperatures of Ikeja, Ijebu Ode, Ibadan and Ilorin (2002-2003). Source: (Nigerian Meterological Station, Oshodi, Lagos)

\section{Abundance of Amphibians}

Table 2 shows the abundance of amphibian species studied in the three vegetation zones in the Southwestern Nigerian. A total mean number of 388 individuals comprising 32 species were recorded in the forest. Seven hundred and sixty-six individuals in 28 species were recorded in the fallowed farmland and 278 individuals in 21 species in the savanna.

The dominant species in the forest was Arthroleptis variabilis $(9.02 \%)$ follwed by Hemisus guineensis (7.99\%) and Hylarana albolabris (7.22\%). The least abundant species in the forest were Leptopelis macrotis, Phlyctimantis boulengeri and Nectophryne afra each having $0.26 \%$. Amietophrynus maculatus and A. regularis were both abundant in the fallowed farmland and savanna habitats. $12.36 \%$ and $10.68 \%$ were recorded for Amietophrynus maculatus and A. regularis in the fallowed farmland respectively and $21.22 \%$ and $14.75 \%$ in the savanna. The least abundant species in the fallowed farmland was Leptopelis calcaratus $(0.13 \%)$ while the least abundant in the savanna were Xenopus muelleri and Afrixalus dorsalis each with $0.72 \%$.

Table 2: Mean abundance of anuran species in the three vegetation zones

\begin{tabular}{|llll|}
\hline Amphibian Species & forest & fallowed farmland & savanna \\
PIPIDAE & & & \\
Silurana tropicalis & $26 \pm 4.08(6.70)$ & $34 \pm 13.39(4.38)$ & --- \\
Xenopus muelleri & $13 \pm 2.45(3.35)$ & $16 \pm 8.12(2.06)$ & $2 \pm 0.11(0.72)$ \\
HEMISOTIDAE & & & $21 \pm 2.51(7.55)$ \\
Hemisus marmoratus & $17 \pm 2.83(4.38)$ & --- & --- \\
H. guineensis & $31 \pm 2.0(7.99)$ & --- & $41 \pm 5.97(14.75)$ \\
BUFONIDAE & $19 \pm 5.86(4.90)$ & $83 \pm 15.73(10.68)$ & $59 \pm 3.48(21.22)$ \\
Amietophrynus regularis & $28 \pm 2.52(7.22)$ & $96 \pm 16.72(12.36)$ & --- \\
A. maculatus & $1 \pm 0.4(0.26)$ & --- & $14 \pm 3.61(5.04)$ \\
Nectophryne afra & $4 \pm 1.53(1.03)$ & $81 \pm 4.32(10.42)$ & \\
DICROGLOSSIDAE & & & \\
Hoplobatrachus occipitalis & & &
\end{tabular}




\begin{tabular}{|c|c|c|c|}
\hline \multicolumn{4}{|l|}{ RANIDAE } \\
\hline Hydrophylax albolabris & $28 \pm 3.32(7.22)$ & --- & --- \\
\hline H. galamensis & --- & $6 \pm 1.21(0.77)$ & $8 \pm 0.71(2.88)$ \\
\hline Aubria subsigillata & $27 \pm 3.06(6.96)$ & $11 \pm 2.83(1.42)$ & --- \\
\hline \multicolumn{4}{|l|}{ PTYCHADENIDAE } \\
\hline Ptychadena pumilio & $3 \pm 0.86(0.78)$ & $71 \pm 12.21(9.14)$ & $21 \pm 4.27(7.55)$ \\
\hline Ptychadena oxyrhynchus & $2 \pm 0.42(0.52)$ & $28 \pm 3.71(3.60)$ & $9 \pm 1.12(3.24)$ \\
\hline Ptychadena bibroni & --- & $26 \pm 5.49(3.35)$ & $6 \pm 3.54(2.16)$ \\
\hline Ptychadena stenocephala & --- & $29 \pm 7.07(3.73)$ & --- \\
\hline Ptychadena taenioscelis & --- & $41 \pm 4.7(5.32)$ & $22 \pm 6.29(7.91)$ \\
\hline Ptychadena mascareniensis & $4 \pm 1.20(1.03)$ & $26 \pm 3.87(3.35)$ & --- \\
\hline Ptychadena longirostris & $2 \pm 0.13(0.52)$ & $15 \pm 2.83(1.93)$ & --- \\
\hline Ptychadena aequiplicata & $27 \pm 1.15(6.96)$ & --- & --- \\
\hline Ptychadena sp & --- & $2 \pm 1.16(0.26)$ & --- \\
\hline \multicolumn{4}{|l|}{ PHRYNOBATRACHIDAE } \\
\hline Phrynobatrachus accraensis & --- & $16 \pm 3.15(2.06)$ & $23 \pm 2.83(8.27)$ \\
\hline Phrynobatrachus alleni & --- & $31 \pm 3.21(4.00)$ & --- \\
\hline Phrynobatrachus francisci & $9 \pm 2.83(2.32)$ & $21 \pm 4.24(2.70)$ & $15 \pm 3.54(5.40)$ \\
\hline Phrynobatrachus plicatus & $3 \pm 0.89(0.78)$ & --- & --- \\
\hline Phrynobatrachus liberiensis & $2 \pm 0.75(0.52)$ & --- & --- \\
\hline Phrynobatrachus glanensis & $2 \pm 0.31(0.52)$ & --- & --- \\
\hline Phrynobatrachus sp & --- & $6 \pm 2.12(0.77)$ & --- \\
\hline \multicolumn{4}{|l|}{ ARTHROLEPTIDAE } \\
\hline Arthroleptis variabilis & $35 \pm 4.06(9.02)$ & $14 \pm 2.06(1.80)$ & $3 \pm 0.64(1.08)$ \\
\hline Arthroleptis poecilonotus & $19 \pm 4.04(4.90)$ & 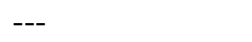 & --- \\
\hline Arthroleptis sp 1 & $3 \pm 1.12(0.78)$ & $4 \pm 0.71(0.51)$ & --- \\
\hline Arthroleptis sp 2 & $4 \pm 2.52(1.03)$ & & \\
\hline Leptopelis viridis & $1 \pm 0.89(0.26)$ & $17 \pm 0.71(2.19)$ & $3 \pm 0.82(1.08)$ \\
\hline Leptopelis hyloides & $4 \pm 1.53(1.03)$ & $16 \pm 0.82(2.06)$ & $9 \pm 0.71(3.24)$ \\
\hline Leptopelis macrotis & $1 \pm 0.63(0.26)$ & --- & --- \\
\hline Leptopelis boulengeri & $4 \pm 1.01(1.03)$ & --- & --- \\
\hline Leptopelis calcaratus & --- & $1 \pm 0.9(0.13)$ & --- \\
\hline \multicolumn{4}{|l|}{ HYPEROLIIDAE } \\
\hline Afrixalus dorsalis & $11 \pm 0.71(2.89)$ & $28 \pm 4.29(3.60)$ & $2 \pm 0.31(0.72)$ \\
\hline Hyperolius nasutus & --- & --- & $3 \pm 1.16(1.08)$ \\
\hline Hyperolius-fusciventris burtoni & $16 \pm 3.11(4.12)$ & $21 \pm 8.23(2.70)$ & $5 \pm 0.71(1.80)$ \\
\hline Hyperolius nitidulus & --- & 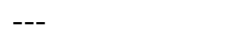 & $4 \pm 2.22(1.44)$ \\
\hline Hyperolius guttulatus & $29 \pm 8.62(7.47)$ & $17 \pm 2.65(2.19)$ & --- - - \\
\hline Hyperolius concolour ibadanensis & $12 \pm 1.41(3.09)$ & $9 \pm 1.52(1.16)$ & $5 \pm 0.71(1.80)$ \\
\hline Kassina senegalensis & --- & --- & $3 \pm 1.41(1.08)$ \\
\hline Phlyctimantis boulengeri & $1 \pm 0.9(0.26)$ & --- & --- \\
\hline
\end{tabular}

Where, numbers in parenthesis are percentages (\%).

Table 3: Community composition parameter / bio-indices

\begin{tabular}{|llll|}
\hline Bio-index & forest & fallow farmland & savanna \\
Total species diversity (S) & 32 & 28 & 21 \\
Total abundance (N) & 388 & 766 & 278 \\
Log of Species diversity (Log S) & 1.51 & 1.45 & 1.32 \\
Log of abundance (Log N) & 2.59 & 2.88 & 2.44 \\
Shannon-Wiener Index (Hs) & 1.32 & 1.29 & 1.13 \\
Margalef Index (d) & 5.2 & 4.07 & 3.55 \\
Equitability(evenness) Index (j) & 0.72 & 0.77 & 0.67 \\
Dominance(D) & 0.051 & 0.058 & 0.1 \\
Simpson 1-D & 0.9426 & 0.9349 & 0.8984 \\
\hline
\end{tabular}


The statistical analysis of the community composition of amphibian species in the three vegetation regions is shown Table 3. The forest had the highest diversity (most species) while the fallowed farmland had the most evenly distributed species (evenness) and the savanna had the least diverse species. The Sorensen's Index calculated between the forest and fallowed farmland was $63.33 \%$; between the forest and savanna was $52.83 \%$ and between the fallowed and savanna was $69.39 \%$. The Analysis of Variance (ANOVA) showed that there was significant difference $\left(\mathrm{F}_{2,129}\right.$ $=3.602$ ) between the numbers of anuran species inhabiting the three vegetation habitats at $\mathrm{P}<0.05$. There was also significant difference $\left(\mathrm{F}_{2}, 129=5.811\right)$ between the number of individuals of anuran species in the three vegetation habitats $(\mathrm{P}<0.01)$. See Appendix for multiple comparison analysis of the means of each vegetation habitat.

\section{Distribution of Amphibian Species in the} Various Vegetation Habitats

Thirty percent of amphibian species were observed in all the vegetation habitats sampled (Table 4). Six species namely; Silurana tropicalis, Ptychadena mascareniensis, $P$. longirostris, Aubria subsigillata, Arthroleptis sp land Hyperolius guttulatus were observed both in the forest and fallowed farmland. This constituted the highest number (14\%) of species observed inhabiting two vegetation types. Only a single amphibian species was observed to inhabit both the forest and savanna which was Hemisus marmoratus. The forest had the highest $(27 \%)$ number of species restricted to its ecosystem, while the savanna had the lowest (7\%) observed. 
Table 4: Habitat preference of amphibian species in the various vegetation habitats

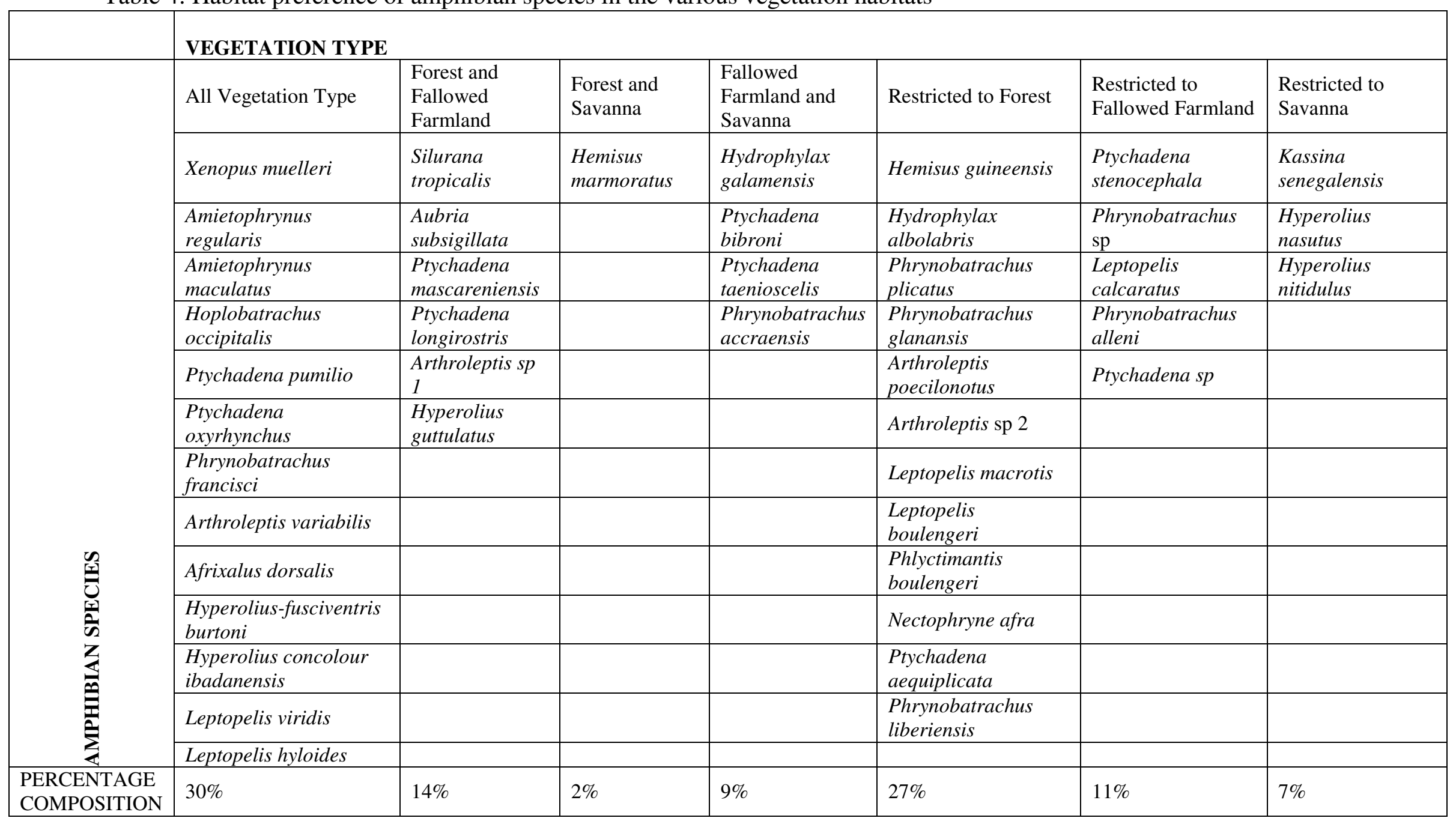


Observation on the Activity Peak of Amphibian Species in the Vegetation Habitats

Most anuran species (13.8 \pm 3.9$)$ and individuals $(42.3 \pm 9.5)$ were observed between 18-21h (Figure 3). The highest number of species was collected in the forest (17) between 18-21h while the lowest in the savanna (2.8) between 12- 15h. The fallowed farmland had the highest number of individuals (52.3) between 6-9h while the least was collected from the savanna (5.7) between 12-15h. Generally, most species were observed to be active in the evening $(18-21 \mathrm{~h})$ in all the sites sampled and the least were observed to be active in the afternoon (12-15h) sampling time.

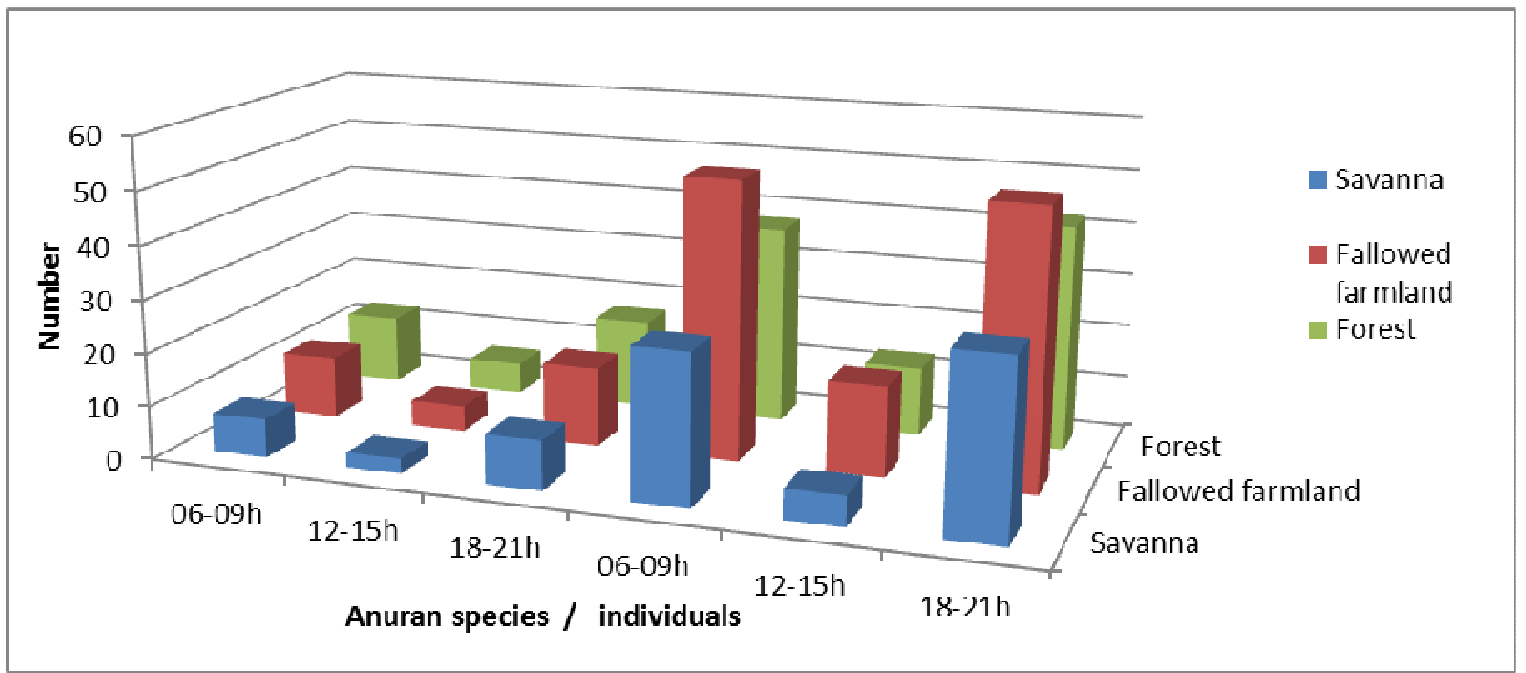

Figure 3: Mean number of anuran species and individuals caught during different time intervals.

\section{Discussion}

This study describes the diversity, distribution and abundance of amphibian species in three vegetation zones: forest, fallowed farmland and savanna in Southwestern Nigeria. The greatest number of anuran species was observed in the forest region (areas around Ikeja, Ijebu Ode and Ibadan) which experience high rainfall and low temperature due to tree canopies which blocks direct rays of sunlight thereby creating a cool environment with high humidity enabling greater thriving conditions. This finding supports the observation of Wells (2007), who reported high density of amphibians in the forests since the relatively constant temperature and wet environment of tropical habitats are ideal for amphibians especially those that lay eggs out of water. Amphibian diversity is also affected by high rainfall experienced in the forest and a strong positive correlation exists between them (Campbell, 1999 and Duellman, 1993). Population size of anurans is controlled mainly by the availability of water for reproduction as food is not a limiting resource in most years (Barbault, 1974). In this study, Hemisus guineensis, Hydrophylax albolabris, Phrynobatrachus plicatus, P. glanansis, Arthroleptis poecilonotus, Arthrolethis sp 2, Leptopolis macrotis, L. boulengeri, Phlyctimantis boulengeri and Nectophryne afra were restricted to the forest region. Rodel and Branch (2002) also reported the presence of four of these species, Hydrophylax albolabris, Phrynobatrachus plicatus, 
Leptopolis macrotis and Phylctimantis boulengeri in the forest of Ivory Coast.

A higher number of individuals but fewer species were reported in the fallowed farmland region (degraded areas around Ikeja, Ijebu Ode and Ibadan) than the forest region. The fallowed farmland has fewer and shorter trees due to the fact that is was previously cleared of the primary forest vegetation before being used as farms. The reduction in amphibian species is a result of the negative effect of habitat destruction on the former forest region. Ukwetang, et al., (2013) observed that in recent times, man has become a predator rather than a protector and has thoughtlessly destroyed the natural landscape through large-scale logging, mechanized farming, forest engineering and construction. Individual amphibian species could easily be observed or collected among the developing vegetation or on the exposed ground because of bush burning or cutting, hence the higher number of individuals observed. The fewer number of individuals reported in the forest may be attributed to the thick undergrowth in some part of the undisturbed forest which made the visual encounter method difficult. The result obtained in this study indicates more species were present in the forest due to the mature vegetation.

The lowest number of species and individuals were recorded in the savanna region (areas mostly around Ilorin). The lowest annual rainfall highest temperature and sparse vegetation were recorded in this area during this study. Amphibians must go back to water for reproduction and the scarcity of water bodies observed in the savanna may have adversely affected reproduction, thereby affecting species richness and number of individuals. Araujo et al., (2006) reported that the decrease in the availability of water in the environment reduces the chances of amphibians to survive in it. Barbult (1972) also observed that drier upland areas with lesser ponds have much lower population densities than lowland areas with abundant temporary ponds. The treefrogs, Kassina senegalensis, Hyperolius nitidulus and $H$. nasutus were found to be restricted in the savanna region in this study. Rodel (2000) reported that Hoplobatrachus occipitalis, Phrynobatrachus accrensis and Ptychadena bibroni were restricted to the savanna in Ivory Coast, but also reported that these species invade other habitats due to destruction of their habitats.

From statistical analysis, the evenness was highest in the fallowed farmland. This shows that the various species observed in this vegetation habitat were more equally distributed than seen in the other vegetation habitats. The evenness was lowest in the savanna, which indicates that the various species observed in this habitat were not equally abundant as the other two habitats. The numbers of individuals of the various species were dissimilar and not as evenly distributed as those in the fallowed farmland habitat. The Shannon-Wiener and Margalef indices measure the species richness of a community, which is independent of the sample size. As expected, the larger the sample sizes the higher the species richness. These two species richness indices were highest in the forest habitat and lowest in the savanna habitat. This shows that the forest habitat had the greatest number of species, indicating the highest diversity, hence greatest biological stability than the fallowed farmland and the savanna. The savanna had the lowest number of species diversity than the other habitats. The reasons as discussed earlier could be due to 
ecological factors such as biotic, climatic, edaphic or topographic.

The Sorenson's index was highest between the fallowed farmland and the savanna and lowest between the forest and savanna. This indicates that there were greater number of similar species inhabiting the fallowed farmland and savanna where as the forest and savanna had the least number of similar species inhabiting them. This could be mainly attributed to the nature of vegetation located in these regions. The fallowed farmland and savanna have almost similar vegetation status, hence the high similarity of species. The both habitats have low vegetation cover as compared to the forests. The forest has a greater range of vegetation with tree canopies as compared to the savanna, thereby creating conducive living conditions for the amphibian species. This increases the number and variety of species of the forest as compared to the savanna habitat of mostly tall grasses and few trees; hence the lowest Sorenson's index between the two vegetation habitats. The significant difference of anuran species and individuals in these different habitats arose from these factors.

Anuran species were mostly observed and collected between 18-21h sampling time frame. This confirms the fact that these species are mostly nocturnal in the habit. Most biological activities such as feeding, mating, foraging, migration etc. are executed during the night. This seems to be the appropriate time because the animal will loose less water through their soft moist skin at night than during the day. Xie et al. (2007) observed that during the day time, the effective camouflage and nocturnal habit of most frogs and toads makes them difficult to see, when they often hide among rocks and crevices, or under leaf litter and bushes. The activity period between $12-15 \mathrm{~h}$ was highest in the forest owing to the fact that direct sunlight was prevented from reaching the forest floor by the tree canopies. This created a cool environment on the forest floor which facilitated the highest activity of anurans at that sampling time compared to other vegetation areas.

\section{Conclusion and Recommendation}

The climatic condition of a region has pronounced effect on the vegetation structure, hence on the distribution, diversity and abundance of biotic components eg. anurans. Anthropogenic activities such as urbanization and unsustainable agricultural practices have detrimental on the natural vegetation which also in a long term affects the climate. The end result will in no small term have a devastating effect on the thriving conditions of the biotic components within these affected zones. There is indeed a rich amphibian fauna in Nigeria, but efforts must be made to preserve the vegetation structure, hence the need of enforcing conservation laws and decrees. All unsustainable forest practices should be strongly prohibited and local indigenes should be trained to enforce these objectives. This will go a long way in protecting and maintaining the biodiversity status of the region especially nature's brilliant gems- the anurans.

\section{References}

Adejuwon, J.O. (1976). Human impact on African environmental systems, in Contemporary Africa: Geography and Change (Knight, G. C. and Newman, J. L., editors) Englewood Cliffs, New Jersey: Prentice-Hall, pp 140-158 
Araujo, M.B., Thuiller, W. and Pearson, R.G. (2006). Climate warming and the decline of amphbians in Europe. Journal of Tropical Ecology 22(6): 695-704.

Ayobami, T.S. (1998) Vegetation modification and man-induced environmental change in rural Southwestern Nigeria. Agriculture, Ecosystems and Environment 70: 159-167

Bakarr, M., Bailey, B., Byler, D., Ham, R., Olivieri, S. and Omland, M. (2001). From the forest to the sea: biodiversity connections from Guinea to Togo, Conservation PrioritySetting Workshop, December 1999.Washington D. C. (Conservation International), 78pp.

Barbault, R. (1972). Les peuplements d'amphidiens des savanes de Lamto (Cote d'Ivoire). Ann. Univ. Abidjan, Ser. E., 5: 59-142

Barbault, R. (1974). Observation ecologiques dans la savanna de Lamto (Cote d' Ivore) Bull. Ecol. 5: 7-25.

Becker, C.G., Fonseca, R.C., Haddad, B.F., Batista, F.R. and Prado, I.P. (2007). Habitat Split and Global Decline of Amphibians Science 318 (5857): 1775-1777

Blaustein, A. and Bancroft, B. (2007). Amphibian Population Declines: Evolutionary Considerations. Bioscience 57 (5):437-444

Boone, M.O. and Bridges, C.M. (2003). A hierarchical approach in studying the effects of an insecticide on amphibians In: Linder, G., Sparling D.W. and Krest, S.K. eds. Multiple Stressors and Declining Amphibians Populations: Evolutionary Cause and Effects. Pensacola: Society of
Environmental Toxicology and Chemistry Press. Pp 265-270

Campbell, J.A. (1999). Distribution patterns of amphibians in Middle America. Pages 111-210 in W.E.

Dulleman (editor), Patterns of Distribution of Amphibans. John Hopkins University Press, Baltimore, Maryland, USA

Conant, R. and Joseph, T. (1998). A Field Guide to the Reptiles and Amphibians of Eastern and Central North America, $3^{\text {rd }}$ ed. Boston Massachusetts Houghton Mifflin.

Duellman, W.E. and Trueb, L. (1986) Biology of Amphibians. McGrawHill Publication Co., Boltimore, M. D. pp. 670

Duellman, W.E. (1993). Amphibian species of the world: additions and corrections. Univ. Kansas Mus. Nat. Hist., Special Publications No. 21, $372 \mathrm{pp}$

FAO. (1985b). Aménagement polyvalent intensif des forêts sous les tropiques. Etudes de cas en Inde, en Afrique, en Amérique latine et aux Antilles. Etude FAO: Forêts $\mathrm{n}^{\circ}$ 55, Rome.

Kio, P.R.O., Ekwebelam, S.A., Oguntala, A.B., Ladipo, D.O. and Nwonwu, F.O.C. (1985) Management systems in tropical mixed forests of Anglophone Africa. Rome. FAO

NEST (Nigerian Environmental Study/Action Team) (1991) Nigeria's Threatened Environment-A National Profile. Intec Printers Limited, Ibadan 288pp

Ogigirigi, M.A. (1986). An approach to development of forest resources of the Sudano-Sahelian zone of Nigeria, in The Challenge of Deforestation in Nigeria. Proceedings of the Forestry Association of Nigeria Conference, (Oguntala, A. B., editor), pp 47-58 
Onadeko, A.B. and Rodel, M.O. (2009). Amphibian surveys in Southwestern Nigeria, West Africa Salamandra 45:1-14

Rodel, M.O. (2000). Herpetofauna of West Africa. Vol. I. Amphibians of the West African Savanna. Edition Chimaira, Frankfurt am Main. 332pp.

Rodel, M.O. and Branch, W.R. (2002). Herpotological survey of the Haute Dodo Cavally forests, Western Ivory Coast. Salamandra, 38(4): 245-268.

Rodel, M.O. and Ernst, R. (2004). Measuring and Monitoring Amphibian Diversity in Tropical Forests. I. An Evulation of Methods with Reccommodation for Standardization. Ecotropica 10: 1-14

Schiotz, A. (1963). The Amphians of Nigeria. Vidensk. Meddr. Dansk Naturl. Foren. 125: 1-92
Udo, R.K. (1970). Geographical Regions in Nigeria. Heinemen Educational London 212pp

Ukwetang, J.O., Neji, H.A. and Onuoha, C.O. (2013). Assessing Indigenous Communities Socio-Economic Status as Catalyst for Forest Resources Conservation in Akamkpa Local Government Area, Nigeria. Journal of Education and Practice. 4(13): 6771

Wells, K.D. (2007). The Ecology and Behaviour of Amphibians. University of Chicago Press 1148pp

Xie, F., Lau, M.W., Stuart, S.N., Chanson, J.S., Cox, N.A. and Fischman, D.C. (2007). Conservation needs of amphibians in China: a review Science in China Series C: Life Sciences 50: 265-2776 